\title{
PERAN GURU DALAM MEMBENTUK ARIF BUDAYA SISWA MELALUI MODEL PEMBELAJARAN THINK PAIR SHARE
}

\author{
Tarsisia Devi \\ tarsisiadevi1@gmail.com \\ PGSD FIP Universitas PGRI Semarang
}

\begin{abstract}
ABSTRAK
Artikel ini ditulis dengan tujuan untuk mengetahui peran guru dalam pembentukkan arif budaya siswa melalui model pembelajaran Think Pair Share. Model pembelajaran Think Pair Share diterapkan untuk meningkatkan daya pikir siswa dalam memecahkan suatu persoalan materi pelajaran, sehingga tercipta budaya siswa untuk berpikir cerdas. Guru mampu membentuk arif budaya siswa. Oleh karena itu guru harus dapat menjadi sumber inspirasi bagi siswa, mampu mengerakkan minat siswa untuk dapat tercipta arif budaya yang baik bagi dirinya. Guru tidak hanya menjadi pendidik, numun juga harus mampu membangkitkan semangat siswa untuk tidak malas berpikir. Metode kajian yang digunakan dalam penulisan artikel ini adalah observasi. Hasil yang diperoleh menunjukkan bahwa guru dituntut sebagai transformator, fasilitator dan motivator dalam pembentukkan arif budaya siswa.
\end{abstract}

Kata kunci: Peran guru, arif budaya, model pembelajaran Think Pair Share

\section{PENDAHULUAN}

Salah satu kebijakan umum pembangunan di Indonesia adalah meningkatkan mutu pendidikan. Pendidikan sangatlah terkait dengan adanya proses belajar mengajar. Sehingga proses belajar mengajar merupakan inti dari kegiatan pendidikan di sekolah. Guru merupakan peran utama dalam suatu pendidikan yaitu untuk menguasai dan mengembangkan materi pembelajaran, merencanakan dan menyiapkan pelajaran, mengontrol dan mengevaluasi kegiatan siswa.

Pendidikan sangat penting untuk mencerdaskan para penerus bangsa. Terutama pendidikan dasar yang harus diberikan kepada peserta didik pada Sekolah Dasar. Maka pendidikan memiliki peran yang sangat penting dalam menciptakan sumber daya manusia yang berkualitas serta peradaban bangsa yang bermartabat dalam mencerdaskan kehidupan bangsa, bertujuan untuk berkembangnya kompetensi peserta didik agar menjadi manusia yang beriman, berakhlak mulia, berilmu, kreatif, mandiri dan menjadi warga negara yang demokratis serta bertanggung jawab.

Arif budaya merupakan kebiasaan yang dilakukan untuk berpikir kritis atau berpikir cerdas. Oleh karena itu peran guru juga sangatlah penting dalam pembentukan arif budaya siswa, hal tersebut sudah menjadi tugas guru untuk sebagai pendidik yang profesional. Dalam melakukan proses pembelajaran di sekolah, siswa tidak hanya belajar tentang teori dan praktek tetapi siswa diajak untuk mencapai aspek kognitifdan psikomotorik, sehingga dapat terwujud kearifan budaya siswa yaitu kebiasaan siswa untuk berpikir cerdas mengkomunikasikan idenya melalui model pembelajaran Think Pair Share. 


\section{Rumusan Masalah}

Bagaimana peran guru dalam pembentukan arif budaya siswa melalui model pembelajaran Think Pair Share?

\section{Tujuan}

Mengetahui peran guru dalam pembentukan arif budaya siswa melalui model pembelajaran Think Pair Share.

\section{Pengertian Guru}

Menurut Pasal 1 ayat(1)UUNo. 14 Tahun 2005 tentang Guru dan Dosen, guru adalah pendidik profesional dengan tugas utamamenidik, mengajar, membimbing, mengarahkan, melatih, menilai dan mengevaluasi peserta didik pada pendidikan anak usia dini jalur pendidikan formal, pendidikan dasar, dan pendidikan menengah.

Dalam proses pendidikan guru adalah orang dewasa yang bertanggung jawab membimbing anak didik menuju kepada situasi pendidikan serta bertanggung jawab memberikan bimbingan atau bantuan kepada anak didik dalam perkembangan jasmani dan rohaninya agar mencapai kedewasaannya, melaksanakan tugasnya sebagai makhlukAllah, khalifah di bumi sebagai makhluk sosial dan sebagai individu yang sanggup mandiri.

Menurut Muhammad AR (2003:70-73) dalam (Agus Wibowo 2012:62), guru itu bukan orang sembarangan. Ia adalah manusia yang memiliki kualitas dalam hal ilmu pengetahuan, moral, cinta, serta ketaatan kepada agama. Oleh karena itu, gerak-gerik seorang guru harus ditata sedemikian rupa, sampai-sampai ketika hendak mengerjakan sesuatu mesti menoleh ke depan, ke depan dan sekitarnya. Karena segenap tindakan guru akan dipantau oleh setiap orang termasuk anak didiknya. Bahkan, polah tingkah seorang guru akan menjadikan cermin, entah bagi anak didiknya, maupun masyarakat sekitar.

Guru ialah siapa saja yang bertanggung jawab terhadap perkembangan anak didik. Dapat diartikan juga orang kedua yang paling bertanggung jawab terhadap anak didik setelah orang tua. Guru adalah pendidik yang menjadi tokoh, panutan dan identifikasi para peserta didik dan lingkungannya, karena itulah guru harus memiliki standar kualitas pribadi tertentu yang mencakup tanggung jawab, wibawa, mandiri dan disiplin.

Dari beberapa pengertian di atas, dapat disimpulkan bahwa guru adalah pendidik profesional dengan tugas utama mendidik peserta didik pada pendidikan anak usia dini jalur pendidikan formal, pendidikan dasar, dan pendidikan menengah.

\section{Peran Guru}

Peran guru adalah seperangkat tingkah laku atau tindakan yang dimiliki seseorang dalam memberikan ilmu pengetahuan kepada peserta didik. Seseorang dikatakan menjalankan peran jika ia menjalankan hak dan kewajiban yang merupakan bagian yang tak terpisahkan dari status yang disandangnya.

Menurut BJ Habibie (2009) dalam (Agus Wibowo 2012:2), peran seorang guru sangat penting, khususnya di tingkat dasardan menengah. Bahkan, demi meningkatkan kualitas dan kemajuan dunia pendidikan, para guru besar senior rela memberikan pendidikan (mengajar) di tingkat dasar.

Guru merupakan faktor dominan yang penting dalam suatu pelaksanaan pendidikan dan menciptakan suatu tujuan pembelajaran. Karena guru memegang peranan dalam proses pembelajaran, dimana proses pembelajaran merupakan inti dari proses pendidikan secara keseluruhan (Rusman 2012: 58). Proses pembelajaran merupakan suatu proses yang mengandung serangkaian perbuatan guru dan siswa atas hubungan timbal balik yang berlangsung dalam situasi edukatif untuk mencapai tujuan tertentu, 
dimana dalam proses tersebut terkandung multiperan dari guru.

Guru memiliki peran yang sangat penting dalam menentukan kuantitas dan kualitas pengajaran yang dilaksanakannya (Daryanto dan Muljo 2012:1). Oleh sebab itu, guru harus memikirkan dan membuat perencanaan secara seksama dalam meningkatkan kesempatan belajar bagi siswanya dan memperbaiki kualitas mengajarnya.

Peran guru dalam pembelajaran sangat erat kaitannya dengan pemberian motivasi belajar siswa dalam menyampaikan materi pelajaran. Sehingga guru dituntut dapat sebagai transformator ilmu pengetahuan kepada siswa dan menciptakan proses pembelajaran yang berkesan.

\section{Arif Budaya Siswa}

Berangkat dari kata “arif” yang memiliki arti yaitu cerdas atau pandai dan juga dapat dikatakan sebagai orang yang paham mengenai ilmu pengetahuan. Lalu pengertian budaya merupakan suatu cara hidup yang berkembang dan dimiliki bersama oleh sebuah kelompok orang dan diwariskan dari generasi ke generasi. Budaya juga dapat diartikan sebagai suatu cara atau kebiasaan yang sering dilakukan secara terus menerus. Sedangkan siswa merupakan pelajar yang akan belajar untuk mendapatkan ilmu pengetahuan dan untuk mencapai pemahaman ilmu yang telah didapat pada dunia pendidikan.

Dengan demikian arif budaya siswa merupakan suatu kebiasaan siswa dalam melakukan proses pembelajaran untuk berpikir cerdas dan kritis.

\section{Model Pembelajaran TPS (Think-Pair- Share)}

Model pembelajaran Think Pair Share merupakan model pembelajaran diskusi kelas untuk saling berbagi gagasan dan bertukar pendapat secara lisan, teratur dan untuk mengekspresikan pikiran tentang pokok pembicaraan tertentu. Pemanfaat diskusi oleh guru mempunyai arti untuk memahami apa yang terdapat di dalam pikiran siswa dan bagaimana memproses gagasan dan informasi yang diajarkan melalui komunikasi yang terjadi selama pembelajaran berlangsung, baik antara siswa maupun komunikasi guru dengan siswa.sehingga diskusi menyediakan tatanan sosial dimana guru dapat membantu siswa menganalisis proses berpikir mereka.

Langkah model pembelajaran TPS menurut Arends (dalam Trianto, 2007:61-62) yaitumeliputi:

1. Langkah 1: Berpikir (Think)

Guru mengajukan suatu pertanyaan atau masalah yang berkaitan dengan pelajaran dan meminta siswa menggunakan waktu beberapa menit untuk berpikir sendiri jawaban atau masalah. Peserta didikmembutuhkan penjelasan bahwa berbicara atau mengerjakan bukan suatu bagian berpikir.

\section{Langkah 2: Berpasangan (Pair)}

Selanjutnya guru meminta siswa untuk berpasangan dan mendiskusikan apa yang telah mereka peroleh. Interaksi selama waktu yang disediakan dapat menyatukan jawaban jika suatu pertanyaan yang diajukan atau menyatukan gagasan apabila suatu masalah khusus yang diidentifikasi. Secara normal guru memberi waktu lebih dari 4 atau 5 menit untuk berpasangan.

\section{Langkah 3: Berbagi (Share)}

Pada langkah akhir, guru meminta pasangan-pasangan untuk berbagi dengan keseluruhan kelas yang telah mereka bicarakan. Hal ini efektif untuk berkeliling ruangan dari pasangan ke pasangan dan melanjutkan sampai sekitar pasangan mendapat kesempatan untuk melaporkan hasil berpikirnya.

Manfaat dari model pembelajaran TPS yaitu: 
1. Memungkinkan siswa untuk bekerja sendiri dan bekerja sama dengan orang lain

2. Megoptimalkan partisipasi siswa dalam proses pembelajaran

3. Melatih keterampilan dan pengetahuan siswa

4. Membiasakan siswa untuk terlatih dengan berpikir cerdas pada waktu mendapat pertanyaan dari guru.

5. Dengan meminta siswa membuat sendiri pertanyaan-pertanyaannya, maka siswa akan lebih terdorong untuk belajar dan menjawab pertanyaan yang dibuat oleh teman-teman sekelasnya.

\section{Peran Guru Dalam Pembentukan Arif Budaya Siswa Melalui Model Pembelajaran TPS}

Peran guru dalam pembentukan arif budaya siswa adalah sebagai pendamping proses pembelajaran dan sebagai transformator menyampaikan ilmu pengetahuan, materi pembelajaran kepada siswa. Untuk membangkitkan motivasi, inovasi dan daya berpikir siswa yang cerdas maka guru memerlukan adanya suatu model pembelajaran. Model pembelajaran Think Pair Share merupakan suatu cara yang digunakan guru dalam proses pembelajaran untuk membangkitkan kebudayaan atau kebiasaan berpikir cerdas kepada siswa yaitu guru memberikan suatu persoalan mengenai materi pelajaran kepada siswa dengan harapan siswa dapat berpikir cerdas dalam memecahkan persoalan materi pelajaran dan menemukan solusi yang tepat. Sehingga di dalam kelas terjadi komunikasi dan interaksi antar siswa mengenai pendapatnya pada solusi persoalan yang diberikan oleh guru. Dengan adanya kebiasaan pembelajaran di dalam kelas seperti itu, maka akan tercipta adanya arif budaya siswa.

\section{PEMBAHASAN}

Hasil yang diperoleh menunjukkan bahwa guru dituntut sebagai transformator, fasilitator dan motivator dalam pembentukan arif budaya siswa. Guru harus dapat memberi bimbingan, pemahaman dan pengaruh positif terhadap siswa. Melalui model pembelajaran Think Pair Share guru harus dapat menciptakan daya berpikir siswa yang cerdas, kritis dan memiliki wawasan luas. Guru juga harus dapat menjadi sumber inspirasi bagi siswa. Selain itu, guru harus dapat berperan sebagai motivator yang mampu menggerakkan minat dan perhatian siswa untuk dapat membentuk arif budaya siswa yang baik dan berkualitas.

Untuk membangkitkan semangat belajar siswa dan berpikir cerdas, guru memberi stimulus kepada siswa yaitu memberikan suatu persoalan mengenai materi pelajaran yang nantinya siswa akan menjawab dari persoalan tersebut dan tahap berpikir siswa seperti itulah merupakan tahap awal dari model pembelajaran TPS yaitu tahap Think, kemudian pada tahap Pair siswa berpasangan mendiskusikan mengenai jawaban yang telah dipikirkannya dan saling bertukar pendapat, pada tahap kedua ini bertujuan untuk melatih ketrampilan sosial siswa dalam berkomunikasi dengan teman sebaya; dan yang ketiga adalah tahap Share yaitu siswa bebagai dengan keseluruhan kelas yang mereka bicarakan mengenai pembahasan jawaban tersebut.

Maka guru harus dapat melakukan proses pembelajaran secara profesional dan mengelola kelas dengan baik sehingga selama pembelajaran berlangsung dengan menggunakan model TPS, siswa tetap tenang mengikuti pelajaran dan terutama siswa dapat aktif selama pembelajaran. Yaitu aktif untuk berpikir cerdas, menjawab pertanyaan guru, mengemukakan pendapat dan bertanya.

Untuk dapat membentuk arif budaya siswa yang baik, guru juga harus memiliki wawasan yang luas untuk memberi stimulus kepada siswa dalam menyampaikan suatu 
persoalan mengenai materi pelajaran yang nantinya akan ditemukan solusinya oleh siswa dalammemecahkan suatu permasalahan tersebut. Maka secara langsung siswa akan terbiasa dengan pola berpikir cerdas dan kritis saat pembelajaran. Sehingga di dalam proses pembelajaran dapat tercipta arif budaya siswa.

\section{SIMPULAN DAN SARAN}

\section{Simpulan}

Dari pembahasan di atas, dapat disimpulkan bahwa peran guru dalam pembentukan arif budaya siswa adalah sebagai transformator, fasilitator dan motivator. Penggunaan model pembelajaran Think Pair Share baik digunakan dalam pembentukan arif budaya siswa karena siswa dapat terlatih dengan kebiasaan untuk berpikir cerdas dan kritis dalam menghadapi suatu persoalan materi pelajaran.

\section{Saran}

Guru perlu memiliki wawasan pengetahuan yang luas terutama saat proses pembelajaran untuk membangkitkan daya berpikir siswa yang cerdas. Guru tidak hanya menjadi pendidik dan pengajar bagi siswa, namun sebaiknya mampu menjadi inispirator dan motivator dalam proses pembelajaran sehingga dapat menciptakan suasana pembelajaran di dalam kelas menjadi aktif untuk menciptakan arif budaya siswa dan memiliki kesan pembelajaran yang didapatkan siswa.

\section{DAFTAR PUSTAKA}

B. Uno Hamzah; Nurdin Mohamad. 2013. Belajar Dengan Pengekatan PAILKEM. Jakarta: Bumi Aksara.

Daryanto; Muljo Raharjo. 2012. Model Pembelajaran Inovatif. Yogyakarta: Gava Media.

Trianto. 2007. Model Pembelajaran Inovatif Berorientasi Kontruktivistik. Jakarta: Prestasi Pustaka.

Syaiful Bahri; Aswan Zain. 2010. Strategi Belajar Mengajar. Jakarta: Rineka Cipta.

Huda, Miftahul. 2013. Model-model Pengajaran dan Pembelajaran. Yogyakarta: Pustaka Pelajar.

Rusman, Dr. 2012. Model-model Pembelajaran. Jakarta: RajaGrafindo Persada.

Agus Wibowo; Hamrin. 2012. Menjadi Guru Berkarakter. Yogyakarta: Pustaka Pelajar.

https://www.google.com/search?q=contoh+ artikel+ilmiah\&ie $=$ utf- $8 \&$ oe $=$ utf- 8 . 